\title{
Submersion time, depth, substrate type and sampling method as variation sources of marine periphyton
}

\author{
M. Richard ${ }^{a, b},{ }^{*}$, C. Trottier $^{a}$, M.C.J. Verdegem ${ }^{c}$ and J.M.E. Hussenot ${ }^{d}$
}

\footnotetext{
a Institut Français de Recherche pour l'Exploitation de la Mer (IFREMER), 17137L'Houmeau, France

${ }^{b}$ Littoral, Environnement et Sociétés (LIENSs), UMR 6250, CNRS-Université de La Rochelle, 2 rue Olympe de Gouges, F-17042 La Rochelle Cedex 01, France

${ }^{c}$ Aquaculture and Fisheries Group, Department of Animal Sciences, Wageningen University, P.O. Box 338, 6700 AH Wageningen, The Netherlands

d Institut Français de Recherche pour l'Exploitation de la Mer (IFREMER), Dept AGSAE, Station d'aquaculture, 85230 Bouin, France
} *: Corresponding author: M. Richard, Tel.: +33 25168 89 46; fax: +33 2514934 12, email address :
marionrichard fr@yahoo.fr

\begin{abstract}
:
Periphyton is an additional food source in African and Asian brackish and freshwater fish ponds. The present study was a preliminary assessment of periphyton development on artificial substrates in temperate marine ponds. The effects of submersion time, substrate type, water depth, and total or partial sampling methods on the quantity and quality of periphyton collected, were evaluated. Four types of substrate (W: wooden poles, S: smooth fiber-glass strips, m: mosquito screen (1 mm-mesh) and $\mathrm{M}$ : garden netting (5 mm-mesh)) were deployed in a marine pond, and periphyton was collected 15 and 30 days later. The total amount of periphyton per substrate unit was collected as one sample or as 5 sub-samples. Results showed that (i) periphyton biomass in a marine pond increased between day 15 and day 30, (ii) more periphyton was collected on mosquito screen than on wooden poles, fiberglass strips and garden netting, (iii) periphyton biomass increased with submersion depth, (iv) sub-sampling leads to an underestimate compared to whole unit sampling, and (v) a correction of periphyton weight must be carried out considering the dissolved inorganic salts present in periphyton samples from marine and brackish ponds. Whole substrate unit sampling using a tube and stopper is recommended to avoid underestimation of periphyton development. Finally, the autotrophic fraction in the periphyton communities was very low compared to periphyton developed on biodegradable substrates in fertilized tropical ponds. Studies on fertilization and use of biodegraded substrates (i.e. long-time submerged wood) are recommended to further optimize periphyton development in temperate marine ponds.
\end{abstract}

Keywords: Periphyton; Fouling; Artificial substrate; Marine pond; Aquaculture 


\section{Introduction}

Periphyton refers to the entire complex of attached aquatic biota on submerged substrates, including associated non-attached organisms and detritus (van Dam et al., 2002). This assemblage comprises bacteria, fungi, protozoa, phyto and zoo-plankton, benthic organisms and detritus (Azim et al., 2005). It can be used as additional food in aquatic production systems. Aquaculture based on periphyton was originally derived from traditional fishing methods known in Africa as Acadja (Welcomme, 1972) and in Asia as Kathas and Samarahs (Van Dam et al., 2002). Artificial substrates are added into aquatic system to enhance the food availability. This semi-extensive aquaculture system is well known to increase the production of fish (Ramesh et al., 1999; Umesh et al., 1999; Azim et al. 2001a). Although widely tested in freshwater fish culture (Azim et al., 2005), the use of periphyton in brackish or marine waters (van Dam et al., 2002; Huchette and Beveridge, 2005; Khatoon et al., 2007) is limited to shrimp (Bratvold and Browdy, 2001; Moss and Moss, 2004; Arnold et al., 2006) and abalone cultures (Kawamura et al., 2005).

Variation of periphyton quantity and quality depends on a range of factors such as (i) submersion time (Azim and Aseada, 2005), (ii) substrate type (Ramesh et al., 1999; Keshavanath et al., 2001; Azim et al., 2002a), and (iii) light intensity and quality (Kirk 1994; Goldsborough et al., 2005). The latter is strongly influenced by the depth of the substrates (Asaeda and Son 2000). Thus, Azim et al. (2001a, 2003b) waited minimum 2 weeks to allow periphyton to develop on the substrates before stocking fishes. Keshavanath et al. (2001) observed that fish production based on periphyton depends on artificial substrate type and preferred to use bamboo rather than PVC pipes or sugarcane bagasse bundles when culturing masheer (Tor khudree) fingerlings. Azim et al. (2001b, 2002a, 2004a) and Keshavanath et al. (2001) pooled several sub-samples of periphyton collected at equally spaced depths along vertical substrates to analyse the composition of periphyton. This pooled sample was 
considered by these authors to represent the mean composition of periphyton developed on substrate, going from the photic zone close to the surface to the aphotic zone above the bottom.

The potential contributions of semi-extensive aquaculture to environmental protection and restoration of coastal areas have been clearly recognised within EU policy. The SEACASE program (Sustainable extensive and semi-extensive coastal aquaculture system in Southern Europe) was started in 2007 to develop sustainable extensive and semi-extensive coastal aquaculture systems in Southern Europe (Conceição et al., 2007). The present SEACASE study is a preliminary assessment of the feasibility to grow periphyton on artificial substrates in temperate marine ponds. The effects of submersion time, substrate type, water depth, and total or partial sampling methods, on the quantity and quality of periphyton collected, were evaluated. The goals of this study were to identify (i) the best periphyton substrate type and (ii) a methodology of periphyton sampling for further studies on periphyton-based marine aquaculture.

\section{Materials and methods}

\section{1. Experimental site and design}

The experiment was carried out from 9 May till 6 June 2007 in a $200 \mathrm{~m}^{2}$ marine pond in the IFREMER-L'Houmeau experimental facilities, located on the Atlantic coast of France, near La Rochelle. Four types of substrates were used for this experiment (Fig. 1): (i) $2.5 \mathrm{~cm}$ wide square wooden poles (fir tree: W), and $5 \mathrm{~cm}$ wide strips of (ii) smooth fiber-glass (S), mosquito screen (1mm-mesh; m) and (iv) garden netting (5mm-mesh; M). The mean submersion depth of the substrates $( \pm \mathrm{SE})$ was $76.3 \pm 2.7 \mathrm{~cm}$ after 15 days of submersion 
whereas it was $66.3 \pm 4.6 \mathrm{~cm}$ after 30 submersion days. The mean submerged surface area $( \pm$ S.E.) was $713 \pm 9.3 \mathrm{~cm}^{2}$ and equal for each substrate type. Eleven poles or strips (called units) of each substrate type were deployed in the marine pond. The units were put $20 \mathrm{~cm}$ apart from the closest other units in 4 parallel rows with 11 units each within a $1.0 \mathrm{~m}$ x $2.4 \mathrm{~m}$ plot, randomly assigning the different unit types to the available locations. The different strip types were suspended in the water column from iron bars fixed on a horizontal wooden frame standing slightly above the surface on poles driven in the bottom, while the pole units were standing in the sediment, under the iron bar.

\section{Total sampling: Influence of substrate type and submersion time}

84

85

On sampling days, four units of each substrate type were randomly collected. All the periphyton on each unit was collected. Sampling was done 15 (23 May 2007; $\mathrm{T}_{15 \mathrm{~d}}$ ) and 30 days after submersion (4-5 June 2007; $\mathrm{T}_{30 \mathrm{~d}}$ ). Collected units were not placed back. In total, 32 units were collected (4 units/type/date x 4 types $\mathrm{x} 2$ dates).

\section{Sub-sampling: Influence of substrate type and submersion depth} (1)

At the end of the experiment $\left(\mathrm{T}_{30 \mathrm{~d}}\right)$, the remaining 3 units of each substrate type $(\mathrm{W}, \mathrm{S}$, $\mathrm{m}, \mathrm{M})$ were sampled in a random order. The submerged area of each unit was divided in five 15-cm-segments starting from the bottom (Fig. 2a: 1: 0-15 cm, 2: 15-30 cm, 3: 30-45 cm, 4: 45-60 cm, 5: 60-75 cm). Each 15-cm sub-sample (i.e. 1 to 5; Fig. 2a) was completely cleaned. The order of the segment cleaning was randomly assigned for each unit. Each sub-sample was next separately stored. In total, 60 samples were collected ( 3 units/type x 4 types x 5 subsamples/unit). 
Total vs. sub-sampling: comparison of both sampling methods

101

Each $15-\mathrm{cm}$ sub-sample was analysed separately. The average periphyton composition on each unit was calculated in two ways (Fig. 2b):

1. Per unit, the data of the five $15-\mathrm{cm}$ sub-samples (1 to 5) were added together, to represent the whole surface area (S-5), and

2. Per unit, the top $(1: 0-15 \mathrm{~cm})$, middle $(3: 30-45 \mathrm{~cm})$ and bottom $(5: 60-75 \mathrm{~cm}) \mathrm{sub}-$ samples were added together, and extrapolated to the total unit area (S-3).

These data were compared with the results of the whole unit samples $(\mathrm{T})$ collected on the same day (30d). 28 data were thus used for each set of comparison ((4 units/types $x 4$ types $)+$ (S-3 or S-5 sampling method 3 units/type * 4 types)).

Three units (one $\mathrm{W}, \mathrm{m}$ and $\mathrm{M}$ ) were incorrectly treated and could not be included in the data set. It explains why the total degree of freedom was lower than expected (Tables 1 through 3).

\subsection{Sampling and storage}

At $\mathrm{T}_{15 \mathrm{~d}}$ and $\mathrm{T}_{30 \mathrm{~d}}$, water temperature $\left({ }^{\circ} \mathrm{C}\right)$, salinity, $\mathrm{pH}$ were measured with a multiparameter probe (HI9828 HANNA) at the water top $15 \mathrm{~cm}$ of three sites in the pond, at 5:00 PM. Mean water temperature, salinity and $\mathrm{pH}( \pm \mathrm{SE})$ were $24.4 \pm 0.76{ }^{\circ} \mathrm{C}, 32.2 \pm 0.14 \mathrm{ppt}$ and $8.1 \pm 0.07$ at $\mathrm{T}_{15 \mathrm{~d}}$ vs. $26.3 \pm 0.93{ }^{\circ} \mathrm{C}, 32.9 \pm 0.14 \mathrm{ppt}$ and $8.2 \pm 0.03$ at $\mathrm{T}_{30 \mathrm{~d}}$. Mean oxygen concentration $( \pm \mathrm{SE})$ was at $6.4 \pm 0.1 \mathrm{mg} . \mathrm{L}^{-1}(92.8 \pm 2.2 \%) \mathrm{T}_{15 \mathrm{~d}}$ and $6.9 \pm 0.1 \mathrm{mg} . \mathrm{L}^{-1}(102.7$

$121 \pm 2.7 \%)$ at $\mathrm{T}_{30 \mathrm{~d}}$. The water samples were collected immediately after the probe recording.

122 Means of suspended matter $( \pm \mathrm{SE})$ and particulate organic matter were $13.7 \pm 1.04 \mathrm{mg} \cdot \mathrm{L}^{-1}$ and $1.9 \pm 0.2 \mathrm{mg} . \mathrm{L}^{-1}$, respectively, at $\mathrm{T}_{15 \mathrm{~d}}$. The suspended matter was composed of $85.9 \pm 0.4 \%$ of 
124 inorganic matter. At $\mathrm{T}_{30 \mathrm{~d}}$, mean $\mathrm{Chl} a$ was $5.3 \pm 0.3 \mu \mathrm{g} \cdot \mathrm{L}^{-1}$. Chlorophyll pigments included $125 \quad 15.2 \pm 1.2$ percent of Phaeophytin $a$.

126

Periphyton

The order and the location of collected units were randomly assigned. Each unit was sampled by putting a PVC tube (diameter of $6 \mathrm{~cm} \times 110 \mathrm{~cm}$ of length) over it and closing it with a $100 \mu \mathrm{m}$-meshed stopper to avoid periphyton loss. The length of the submerged part of the collected substrate was measured in order to calculate the exact substrate area with periphyton $\left(\mathrm{cm}^{2}\right)$. Each unit was carefully and completely cleaned with fingers and a toothbrush into a plastic flask with a fixed volume of $0.7 \mu \mathrm{m}$-filtered sea-water $(200 \mathrm{ml}$ for total unit samples and $40 \mathrm{ml}$ for $15-\mathrm{cm}$ samples). All material from the inner part of the net of meshed substrates was removed. Each sample was next sub-sampled using a Motoda boxsplitter (Motoda, 1959): 1/8 part was stored in a dark box at $-20^{\circ} \mathrm{C}$ for Chla analysis, $7 / 16$ parts were stored with $4 \%$ formalin for taxonomic analysis, and 7/16 parts were used for periphyton weight analyses, putting it directly in pre-weighted box at $60^{\circ} \mathrm{C}$.

\subsection{Sample analyses}

\section{Dry weight and Ash free dry weight}

Periphyton samples were dried at $60^{\circ} \mathrm{C}$ for $72 \mathrm{~h}$, weighed (DW: dry weight), and burned for $4 \mathrm{~h}$ at $450^{\circ} \mathrm{C}$ to calculate the ash-free dry weight (AFDW; Byers et al., 1978). DW, AFDW and the weight of ash (ASH) were measured to the nearest $10^{-5} \mathrm{~g}$ with an AE240 Mettler Toledo Balance. As filtered sea-water was used to clean units, "salt correction" was applied on 
149 periphyton weight. The effects of added filtered seawater (7/16 of $200 \mathrm{ml}$ or $40 \mathrm{ml}$ according

150 to the type of sampling) on DW, ASH and AFDW of periphyton were determined considering

151 the salinity of the cleaning water and the corresponding calibration curves (DW $\left(\mathrm{g} \cdot \mathrm{L}^{-1}\right)=1.17$

152 Salinity $\left(\mathrm{R}^{2}=0.99\right)$, ASH $\left(\mathrm{g} \cdot \mathrm{L}^{-1}\right)=0.94$ Salinity $\left(\mathrm{R}^{2}=0.99\right)$, and AFDW $\left(\mathrm{g} \cdot \mathrm{L}^{-1}\right)=0.23$ Salinity

$153\left(\mathrm{R}^{2}=0.96\right)$. These equations were established using based on DW, AFDW and ASH content of

154 three replicates of $0.7 \mu \mathrm{m}$-filtered water in which the salinity was either $0,10.7,20.4,28$,

$15528.7,36.37,36.42,38.03,38.12,40.17$ or 40.38 ppt. Sea-water (28 to 40) was collected in

156 marine ponds. Water in which the salinity ranged from 10 to 20 corresponded to diluted sea

157 water by Milli-Q water (0 ppt).

158 Values were reported to the total sample volume (200 or $40 \mathrm{ml}$ ) and to the total length of the 159 unit. DW, ASH and AFDW were thus expressed in $\mathrm{mg} . \mathrm{cm}^{-2}$.

160

Chlorophyll $a$ and Phaeophytin a

162

Chlorophyll $a(\mathrm{Chl} a$ ) and phaeophytin $a$ (Phaeo $a$ ) observed in periphyton were

164 determined with a Turner TD 700 fluorometer after 12 hours of acetone extraction at $4{ }^{\circ} \mathrm{C}$ in

165 the dark without and with acidification. Nine $\mathrm{ml}$ of $100 \%$ acetone were added to $1 \mathrm{ml}-$ 166 periphyton as could performed Azim's team (M.C.J. Verdegem, Pers. Com.). Chl $a$ and Phaeo

$167 a$ data were reported to the total sample volume $(200$ or $40 \mathrm{ml}$ ) and to the total length of the

168 unit. Values were expressed in $\mu \mathrm{g} . \mathrm{cm}^{-2}$ for periphyton. The ratio of phaeophytin vs. sum of

169 chlorophyll pigments was also calculated as (Phaeo $a$ ). (Phaeo $a+\mathrm{Chl} a)^{-1}$ and expressed in \%

170 (\% Phaeo $a)$. The autotrophic index (AI) was calculated as: AFDW (mg.cm $\left.{ }^{-2}\right) / \mathrm{Chl} a\left(\mu \mathrm{g} . \mathrm{cm}^{-}\right.$

1712 ) $* 1000 \mu \mathrm{g} / \mathrm{mg}$ (APHA 1992).

172

173

\subsection{Statistical analyses}


174

175

176

177

178

179

180

181

182

183

184

185

186

187

188

189

190

191

192

193

194

195

196

197

198

The assumptions of normality and homoscedasticity were evaluated using ShapiroWilk (Shapiro and Wilk, 1965) and Brown-Forsythe (Brown and Forsythe, 1974) tests, respectively. When required, data were transformed to satisfy both assumptions. ANOVAs were next performed to test the influence of (i) submersion time (TIME), (ii) substrate type (TYPE), (iii) submersion depth (DEPTH), (iv) sampling method (SAMPLING), and (v) their interactions on periphyton DW, AFDW, Chl $a$, Phaeo a, \%Phaeo $a$ and AI. Tukey's HSD (honestly significant differences) pairwise multiple comparison tests were used to identify the differences when a source of variation was significant $(\mathrm{P}<0.05)$.

\section{Results}

\subsection{Total sampling: Influence of submersion time and substrate type}

According to the ANOVA results (Table 1), dry weight, ash free dry weight, chlorophyll $a$ and phaeophytin $a$ varied significantly among submersion time (TIME; Table 1). Means were greater at $T_{30 d}$ than at $T_{15 d}$. Mean AFDW and Phaeo $a$ were more than twice higher at $\mathrm{T}_{30 \mathrm{~d}}$ than at $\mathrm{T}_{15 \mathrm{~d}}$ (DW: $6.3 \mathrm{mg} . \mathrm{cm}^{-2}$ vs. $2.3 \mathrm{mg} . \mathrm{cm}^{-2}$ and Phaeo $a: 0.2 \mu \mathrm{g} . \mathrm{cm}^{-2}$ vs. 0.1 $\mu \mathrm{g} . \mathrm{cm}^{-2} ;$ Fig. 3a, b).

Substrate type (TYPE) significantly affected the amount of periphyton collected in terms of DW, AFDW, Chl $a$ and Phaeo $a$ (Table 1). Tukey HSD tests revealed that means of DW, AFDW, Chl $a$ and Phaeo $a$ were larger on mosquito screen (m) that on the other substrate types (M, S or W; Fig. 3c, d). Mean periphyton DW and total chlorophyll pigment varied between 3.4 and $6.4 \mathrm{mg} . \mathrm{cm}^{-2}$ (Fig. 3c) and between 0.5 and $1 \mu \mathrm{g} . \mathrm{cm}^{-2}$, respectively, among substrate types (Fig. 3d). 
The interaction of both factors (TYPE x TIME) was a significant variation source of $\%$

Phaeo $a$ (Table 1$)$. Relatively more Phaeo $a$ was present on mosquito screen at $\mathrm{T}_{30 \mathrm{~d}}\left(\mathrm{~m}-\mathrm{T}_{30 \mathrm{~d}}\right.$ : $27.7 \%)$ than at $\mathrm{T}_{15 \mathrm{~d}}\left(\mathrm{~m}-\mathrm{T}_{15 \mathrm{~d}}: 16.7 \%\right)$. In contrast, mean $\%$ Phaeo $a$ did not significantly differ

over time on wooden poles (W), fiber-glass $(\mathrm{S})$ and garden netting $(\mathrm{M})$. Means $( \pm \mathrm{SE})$ were respectively $30.2 \pm 0.9 \% ; 28.2 \pm 1.1 \%$ and $18.7 \pm 1.6 \%$. At $\mathrm{T}_{15 \mathrm{~d}}$, a higher $\%$ Phaeo $a$ was observed on smooth substrates $(\mathrm{W}, \mathrm{S})$ than on meshed substrates $(\mathrm{m}, \mathrm{M})$. At $\mathrm{T}_{30 \mathrm{~d}}$, the \% Phaeo $a$ observed on wooden poles (W) was higher than on garden netting (M). more than 6 times lower at $\mathrm{T}_{15 \mathrm{~d}}(1554 \pm 410)$ than at $\mathrm{T}_{30 \mathrm{~d}}(9449 \pm 1479)$. In contrast, the mean

AI observed on the other substrates $(\mathrm{S}, \mathrm{m}, \mathrm{M})$ did not vary over time.

\subsection{Sub-sampling: Influence of substrate type and submersion depth}

Chl $a$, \% Phaeo $a$ and the AI were significantly different among substrate type (Table 2). HSD tests showed that at $\mathrm{T}_{30 \mathrm{~d}}$, the Chl $a$ mean was greater on meshed substrates and

215 fiberglass than on wooden poles (m, M, S: $0.6 \pm 0.12 \mu \mathrm{g} \cdot \mathrm{cm}^{-2}>\mathrm{W}: 0.26 \pm 0.08 \mu \mathrm{g} \cdot \mathrm{cm}^{-2}$ ). At $\mathrm{T}_{30 \mathrm{~d}}, \%$ Phaeo $a$ varied such as $\mathrm{W}>\mathrm{S}, \mathrm{M} \geq \mathrm{M}, \mathrm{m}$. The AI mean was almost three times higher on wooden poles (W: $2815 \pm 816)$ than on the other substrates $(\mathrm{S}, \mathrm{M}, \mathrm{m}: 939 \pm 299)$. 2). More periphyton was collected at $60-75 \mathrm{~cm}$ depth than at 0-15 $\mathrm{cm}$ depth (Fig. 4). 220 Respectively 2 and 12 times more DW and total chlorophyll $a$ was collected in the bottom 15 $\mathrm{cm}$ than at the top $15 \mathrm{~cm}$. Mean differences between sampling depths of DW and Phaeo $a$ were not statistically significant whereas means seemed to increase between 15 and $60 \mathrm{~cm}$ 
224

225

more than three times larger in the top $15 \mathrm{~cm}(3406 \pm 1002)$ than between 15 and $60 \mathrm{~cm}(900$ \pm 260 ). The $\%$ Phaeo $a$ did not vary with depth whatever the type substrate (Table 2) and was $25.7 \pm 2.05 \%$.

\subsection{Total vs. sub-sampling: comparison of both sampling methods}

Five sub-sampling

The mean DW, AFDW, Chl $a$ and Phaeo $a$ differed significantly between sampling methods (SAMPLING (S-5 vs. T); Table 3). Means were higher with the total sampling (T) than the S5 sub-sampling method whatever the substrate type (Fig. 5a, b). It was particularly right for periphyton quantity rather than quality. DW and AFDW determined through S-5 sampling were 2 and 8 times, respectively lower than $\mathrm{T}$ means (Fig. 5a) whereas the mean of chlorophyll pigment obtained with S-5 sampling corresponded to $82.6 \%$ of means obtained with total sampling $\mathrm{T}$ (Fig. 5b).

\section{Three sub-sampling}

\section{Sampling was a significant source of variation for DW and AFDW (SAMPLING (S-3}

vs. T); Table 3). More DW and AFDW were measured with total sampling (T) than with the S-3 sub-sampling method (Fig. 5a). As S-5 means, S-3 means of DW and AFDW were 2 and 8 times, respectively, lower than the T means (Fig. 5a). In contrast, Chl $a$ and Phaeo $a$ means did not significantly differ between S-3 and T (Fig. 5b).

\section{Discussion}




\subsection{Marine periphyton and its variation sources}

Marine periphyton

A thin mat of matter was observed on all the immersed surface of the different types of substrate after 15 days of submersion. The inorganic fraction of periphyton (ASH) could originate from trapping of suspended inorganic particles. The latter would be favoured during resuspension caused by wind driven turbulence or people working around units during sampling. The organic matter (AFDW) fraction originated from the accumulation of detritus, bacteria, fungi, flora and fauna on substrates. The presence of photosynthetic pigments (Chl $a$ and Phaeo $a$ ) could indicate flora colonization of artificial substrates. The presence of phaeophytin $a$ indicated that the flora observed was partly degraded (15 to $30 \%$ ). The mean autotrophic index ranged between $250(60-75 \mathrm{~cm}$ section of mosquito screen at T30d) and 9450 (wooden poles at $\mathrm{T}_{30 \mathrm{~d}}$ ). These high values indicate that the periphyton contained mainly heterotrophic organisms and dead organic matter, as specified by Huchette et al. (2000) for an AI above 200. In situ observations showed that periphyton was also composed of detritus and small-sized organisms as harpacticoid copepods (Richard et al., unpublished data).

Submersion time

A significant increase of periphyton DW, AFDW and photosynthetic pigments was shown on all substrate types. According to periphyton colonization models (Hoagland et al., 1982; Steinman, 1996), AFDW and Chl $a$ levels increase exponentially until a biomass peak. Organisms at the base of the biofilm become light and nutrient limited, eventually die and 
274 2001a; Azim and Aseada, 2005). In this investigation, periphyton was still in its accretion 275 phase on day 30 on all substrate types. As noted Eding et al. (2006), biofilm establishment

Substrate type

DW, AFDW, Chl $a$, Phaeo $a$ and \%Phaeo $a$ varied according to substrate type. Keshavanath et al. (2001) showed that biodegradable substrates could be more efficient than synthetic substrates (eg. Bamboo vs. PVC tubes) because of the nutrient leaching that occurred at the substrate-water interface (van Dam et al., 2002). In the same way, Anderson and Underwood (1994) reported higher recruitment by epifauna on plywood than on fibreglass or aluminium substrates in an estuary. In contrast, periphyton biomass was not larger on natural (i.e. wooden poles) than on fiberglass strips in this study. 30 dayssubmersion time might have been too short to permit to a significant nutrient leaching at the interface of wooden poles. Nevertheless, the periphyton grown on wooden poles contained relative more phaeophytin (higher $\%$ Phaeo $a$ ) and non autotrophic matter (higher AI) than the other substrates. The observed increase in AI could have originated from uptake of decomposition products from the wood.

More dry matter and Chl $a$ were found on meshed substrates (mosquito and garden meshes) than on smooth substrates (i.e. wood and fiber-glass). The meshes might favour the trapping of particles, in contrast to smooth surfaces. Moreover, higher circulation of water and nutrients across the meshed substrates could stimulate periphyton growth and explain this result. 
The substrate type could also influence the nature of the heterotrophic associated community.

Richard et al. (2007) observed that mesh substrates, as aquaculture pens, offered appropriate

structures for infauna, as Corophium sp. whereas newly submerged smooth substrate, favoured epifauna recruitment. In this study, some polychaete tubes were observed on mosquito screen, but not on smooth substrates. The results of this study indicate that more and qualitatively better periphyton grew on mosquito screen than on the other substrates.

\section{Submersion depth}

The light intensity and its spectral composition change with depth, influencing the quality and type of flora (Boston and Hill, 1991; Hansson, 1992; Kirk, 1994), as periphyton

310 (Goldsborough et al., 2005). In contrast to the observations of Azim et al. (2002a), periphyton DW and chlorophyll pigments increased with depth in this investigation. A decrease of the 10 cm-water level at $T_{30 d}$ could explain why less periphyton was collected on the 0-15 cm part of substrates than on the deeper parts. Nevertheless, the lower chlorophyll pigment concentration

314 observed on the $15-60 \mathrm{~cm}$ part of substrates compared to the deeper part $(60-75 \mathrm{~cm})$ could be 315 due to a photo-inhibition processes, as Hansson (1992) suggested when periphyton Chl $a$ was negatively correlated with light. Unfortunately, light incidence was not measured during this 317 study.

318 Maximal periphyton biomass could be observed where the combination of light and nutrient 319 are optimal (Hansson et al., 2002). In this way, periphyton observed on the deeper part of 320 substrates could have the advantage over the one observed on the surface part by benefiting 321 from nutrient released at the water-sediment interface. Moreover it could benefit from trapping suspended sediment and microphytobenthos present at the bottom of the pond. 


\subsection{Comparisons}

Sampling method

The sum of 3 samples taken between $0-15 \mathrm{~cm}, 30-45 \mathrm{~cm}$ and $60-75 \mathrm{~cm}$ (S-3 method)

led to comparable Chl $a$ and Phaeo $a$ means with the ones obtained with total sampling (T).

That was not the case with S-5 method. Nevertheless, the DW and AFDW of the periphyton collected with both sub-sampling methods (S-5 and S-3) were significantly lower than with

handling for cutting before periphyton collection. Each handling event results in losses, making both the S-5 and S-3 methods less accurate than whole unit sampling. Total sampling was easier and more periphyton was collected. In further studies, the total sampling method will be preferred to sub-sampling one.

In this investigation, the use of $200 \mathrm{ml}$ of filtered salt-water for unit cleaning induced over-estimation of periphyton weight. The DW, the ASH and the AFDW added when cleaning $750 \mathrm{~cm}^{2}$-periphyton substrate with $200 \mathrm{ml}$ of $0.7 \mu \mathrm{m}$ seawater of $32.55 \mathrm{ppt}$ were

340 respectively $10.1,8.1$ and $2 \mathrm{mg} \cdot \mathrm{cm}^{-2}$. These values are very important compared to the real periphyton weight (Table 4), especially for DW and ASH. Without the salt correction, ASH would be more than 6 times greater than the real values (with correction) at $\mathrm{T}_{15 \mathrm{~d}}$ and 3 times at $\mathrm{T}_{30 \mathrm{~d}}$. Analysis of three blanks of cleaning water should be envisaged at each sampling date in

344 subsequent studies. To avoid the salt correction, the use of milliQ water could be envisaged in 345 case where the determination of periphyton weight would be the only analysis to carry out on 346 the sampled unit. The periphyton fauna and flora could be analysed from other units cleaned with filtered seawater to avoid osmotic shock of the living cells. 
Periphyton in other aquatic systems

Absolute values which described the quantity and the quality of periphyton developed

on our substrates deployed in marine water were different with the one observed mainly in freshwater by others authors (Table 4). The mean DW observed on our substrates reached 8.8 mg.cm ${ }^{-2}$ on mosquito screen $\mathrm{m}$ at $\mathrm{T}_{30 \mathrm{~d}}$ (Table 4). This is relatively high since 10 studies out of 13 found a DW $<5 \mathrm{mg} \cdot \mathrm{cm}^{-2}$. Maximal mean organic periphyton (AFDW) observed in this study $\left(4.5 \mathrm{mg} . \mathrm{cm}^{-2}\right)$ was greater than means observed by others authors which generally did not exceed $1 \mathrm{mg} . \mathrm{cm}^{-2}$ with the exception of Azim et al., 2002b (Table 4). In contrast to this investigation, in most of the cited studies, periphyton substrates are simply removed from the water causing probably a lot of loosely attached to be lost and could explain lower mean of AFDW. The use of a tube with a stopper for substrate sampling is recommended to avoid underestimation of periphyton development.

High autotrophic index of this investigation (Table 4) was induced by greater AFDW but also by very low chlorophyll $a$ concentration observed on substrates $\left(0.4\right.$ to $0.6 \mu \mathrm{g} . \mathrm{cm}^{-2}$; Fig. $\left.3 \mathrm{~b}\right)$.

364 Numerous studies observed Chl $a$ levels above 10-15 $\mu \mathrm{g} . \mathrm{cm}^{-2}$ (Azim et al., 2001b,c, 2002a

365 2003a; Keshavanath et al., 2001; Table 4). Low periphyton concentration could originate 366 partly from the use of inert substrate (Huchette et al. 2000; Azim et al. 2003b; Liboriussen and Jeppesen, 2006; This study: Table 4) rather than nutrient-leaching substrate (Azim et al., 2001b, 2002a, 2002b). Nevertheless, others factor could influence the primary productivity, such as temperature, light and nutrient availability (Liboriussen and Jeppesen, 2005; Vermaat 370 et al., 2005). The high densities of periphyton recorded by Azim et al. (2001b, 2002a, 2002b) and Keshavanath et al. (2001) were observed in tropical ponds in Bangladesh and India with more light and higher temperatures than in temperate ponds in France, in the Netherlands 
374 column where mean Chl $a$ was above $200 \mu \mathrm{g} \cdot \mathrm{L}^{-1}$ in Bengali fresh ponds (Azim et al. 2002b),

375 whereas it was $5 \mu \mathrm{g} . \mathrm{L}^{-1}$ in our temperate marine pond. Productivity in freshwater is generally

376 higher than in marine water. However, the ponds were fertilized with urea, manure, food in

377 most studies listed in Table 4 whereas our pond was not fertilized. Azim et al. (2001c, 2003a)

378 showed that periphyton biomass increased with increasing fertilization rate up to a maximum.

379 Thus, in future studies, as part of EU policy of environmental protection and restoration of 380 coastal areas, fertilized effluents of intensive farms could be used to maximise periphyton 381 production and the associated production of herbivorous fishes.

The present investigation showed that (i) periphyton biomass in a marine pond

384 increased between day 15 and day 30, (ii) more periphyton was collected on mosquito screen

385 than on wooden poles, fiberglass strips or garden netting, (iii) periphyton biomass increased 386 with water depth submersion, (iv) sub-sampling methods underestimated periphyton 387 development compared to whole unit sampling, and (v) a correction of periphyton biomass 388 must be carried out for the dissolved inorganic salts present in marine or brackish systems 389 using blank weight of cleaning salt filtered water. The use of a tube with stopper for substrate 390 sampling will reduce periphyton sampling losses. Finally, the autotrophic fraction in the 391 periphyton communities was very low compared to periphyton developed on biodegradable 392 substrates used in fish cultures in fertilized tropical ponds. Thus, pond fertilization and use of 393 biodegraded substrates (i.e. long-time submerged wood) should be envisaged in further 394 studies on periphyton-based marine aquaculture in temperate regions. 
This study has been carried out with the financial support from the Commission of the

399 European Communities, specific RTD programme "Specific Support to Policies", SSP-200544483 “SEACASE - Sustainable extensive and semi-intensive coastal aquaculture in Southern

401 Europe", and does not necessarily reflect the European Commission views and in no way 402 anticipates the Commission's future policy in this area. This study was co-funded by the 403 IFREMER institute. This paper was written thanks to the administrative help of $\mathrm{P}$. 404 Bustamante and L. Picard (CNRS, UMR 6250, University of La Rochelle). The authors thank 405 M. Prineau and N. Lachaussée for their advice and help during structure and substrate construction. Thanks go to G. Colli, C. Couturier, N. Lachaussée, F. Mornet and L. Pavie for 407 their precious help in the field. Finally, authors thank A. Bodoy, M.L Begout, M. Breret, L. 408 Joassard, B. Lebreton and P. Richard for the loan of materials.

\section{References}

411 Anderson, M.J., Underwood, A.J., 1994. Effects of substratum on the recruitment and 412 development of an intertidal estuarine fouling assemblage. J. Exp. Mar. Biol. Ecol. 184, $413 \quad 217-234$

414 APHA, 1992. Standard Methods for the examination of water and wastewater. American $415 \quad$ Public Health Association, Washington DC.

416 Arnold, S.J., Sellars, M.J., Crocos, P.J., Coman, G.J., 2006. Intensive production of juvenile 417 tiger shrimp Penaeus monodon: An evaluation of stocking density and artificial substrates. $418 \quad$ Aquaculture 261, 890-896.

419 Asaeda, T., Son, H.D., 2000. Spatial structure and populations of a periphyton community: a 420 model and verification. Ecological Modelling 133, 195-207. 
Azim, M.E., Asaeda, T., 2005. Periphyton structure, diversity and colonization. In: Azim, M.E., Beveridge, M.C.M., van Dam, A.A., Verdegem, M.C.J. (Eds.), Periphyton: Ecology, exploitation and management. CABI Publishing, pp. 15-34.

Azim, M.E., A, M., Wahab, M.A., Verdegem, M.C.J., 2003a. Periphyton-water quality relationships in fertilized fishponds with artificial substrates. Aquaculture 228, 169-187.

Azim, M.E., Verdegem, M.C.J., van Dam, A.A., Beveridge, M.C.M., 2005. Periphyton: Ecology, exploitation and management. CABI Publishing, 319 pp.

Azim, M.E., Wahab, M.A., van Dam, A.A., Beveridge, M.C.M., verdegem, M.C.J., 2001a. The potential of periphyton-based culture of two Indian major carps, rohu Labeo rohita (Hamilton) and gonia Labeo gonius (Linnaeus). Aquacult. Res. 32, 209-216.

Azim, M.E., Rahaman, M.M., Wahab, M.A., Asaeda, T., Little, D.C., Verdegem, M.C.J., 2004b. Periphyton-based pond polycultre system: a bioeconomic comparison of on-farm and on-station trials. Aquaculture 242, 381-396.

Azim, M.E., Verdegem, M.C.J., Singh, M., van Dam, A.A., Beveridge, M.C.M., 2003b. The effects of periphyton substrate and fish stocking density on water quality, phytoplankton, periphyton and fish growth. Aquacult. Res. 34.

Azim, M.E., Verdegem, M.C.J., Khatoon, H., Wahab, M.A., van Dam, A.A., Beveridge, M.C.M., 2002a. A comparison of fertilization, feeding and three periphyton substrates for increasing fish production in freshwater pond aquaculture in Bangladesh. Aquaculture 212.

Azim, M.E., Verdegem, M.C.J., Rahaman, M.M., Wahab, M.A., van Dam, A.A., Beveridge, M.C.M., 2002b. Evaluation of polyculture of Indian major carps in periphyton-based pond. Aquaculture 131-149. 
Azim, M.E., Wahab, M.A., Biswas, P.K., Asaeda, T., Fujino, T., Verdegem, M.C.J., 2004a. The effect of periphyton substrate density on production in freshwater polyculture ponds. Aquaculture 232, 441-453.

Azim, M.E., Wahab, M.A., van Dam, A.A., Beveridge, M.C.M., Huisman, E.A., Verdegem, M.C.J., 2001b. Optimization of stocking ratios of two Indian major carps, rohu (Labeo rohita Ham.) and catla (Catla catla Ham.) in a periphyton-based aquaculture system. Aquaculture, 33-49.

Azim, M.E., Wahab, M.A., van Dam, A.A., Beveridge, M.C.M., Milstein, A., Verdegem, M.C.J., 2001c. Optimization of fertilization rate for maximizing periphyton production on artificial substrates and the implications for periphyton-based aquaculture. Aquacult. Res. $32,749-760$.

Boston, H.L., Hill, W.R., 1991. Photosynthesis-light relations of stream periphyton communities. Limnol. Oceanogr. 36, 644-656.

Bratvold, D., Browdy, C.L., 2001. Effects of sand sediment and vertical surfaces (AquaMats $^{\mathrm{TM}}$ ) on production, water quality, and microbiological ecology in an intensive Litopenaeus vannamei culture system. Aquaculture 195, 81-94.

Brown, M.B., Forsythe, A.B., 1974. Robust tests for the equality of variances. J. Am. Stat. Ass. 69, 364-367.

Byers, S.C., Mills, E.L., Stewart, P.L., 1978. A comparison of methods of determining organic carbon in marine sediments, with suggestions for a standard method. Hydrobiologia 58, 43-47.

Conceição, L.E.C., Cunha, M. E., Yúfera, M., Hussenot, J., Blachier, P., Anras, L., Bailly, D., Marino, G., Cataudella, S., Patarnello, T., Divanach, P., Kentouri, M. and M.T. Dinis, 2007. Sustainable extensive and semi-intensive coastal aquaculture in Southern Europe - 
the SEACASE project. In Competing claims Aquaculture Europe 07, book of abstracts, p 120.

Eding, E.H., Kamstra, A., Verreth, A.V., Huisman, E.A., Klapwijk, A., 2006. Design and operation of nitrifying trickling filters in recirculating aquaculture: A review. Aquacult. Eng. 34, 234-260.

Goldsborough, L.G., McDougal, R.L., North, A.K., 2005. Periphyton in freshwater lakes and wetlands, Periphyton: Ecology, exploitation and management. CABI Publishing, pp. 7198.

Hansson, L.A., 1992. Factors regulating periphytic algal biomass. Limnol. Oceanogr. 37, 322328.

Hoagland, K.D., Roemer, S.C., Rosowski, J.R., 1982. Colonization and community structure of two periphyton assemblages with emphasis on the diatoms (Bacillariophyceae). Am. J. Bot. $69,188-213$.

Huchette, S.M.H., Beveridge, M.C.M., 2005. Periphyton-based cage aquaculture, Periphyton: Ecology, exploitation and management. CABI Publishing, pp. 237-245.

Huchette, S.M.H., Beveridge, M.C.M., Baird, D.J., Ireland, M., 2000. The impacts of grazing by tilapias (Oreochromis niloticus L.) on periphyton communities growing on artificial substrate in cages. Aquaculture 186, 45-60.

Kawamura, T., Roberts, R.D., Takami, H., 2005. Importance of periphyton in Abalone culture, Periphyton: Ecology, exploitation and management. CABI Publishing.

Keshavanath, P., Gangadhar, B., Ramesh, T.J., van Dam, A.A., Beveridge, M.C.M., Verdegem, M.C.J., 2004. Effects of bamboo substrate and supplemental feeding on growth and production of hybrid red tilapia fingerlings (Oreochronis mossambicus $\mathrm{x}$ Oreochromis niloticus). Aquaculture 235, 303-314. 
Keshavanath, P., Gangadhar, B., Ramesh, T.J., van Rooij, J.M., Beveridge, M.C.M., Baird, D.J., Verdegem, M.C.J., van Dam, A.A., 2001. Use of articicial substrates to enhance production of freshwater herbivorous fish in pond culture. Aquacult. Res. 32.

Khatoon, H., Yusoff, F., Banerjee, S., Shariff, M., Sidik Bujang, J., 2007. Formation of periphyton biofilm and subsequent biofouling on different substrates in nutrient enriched brackishwater shrimp ponds. Aquaculture 273, 470-477.

Kirk, J.T.O., 1994. Light and photosynthesis in Aquatic ecosystems. Cambridge University Press, Cambridge, Massachussetts.

Liboriussen, L., Jeppesen, E., 2003. Temporal dynamics in epipelic, pelagic and epiphytic algal production in a clear and a turbid shadow lake. Freshw. Biol. 48, 418-431.

Liboriussen, L., Jeppesen, E., 2006. Structure, biomass, production and depth distribution of periphyton on artificial substratum in shallow lakes with contrasting nutrient concentrations. Freshw. Biol. 51, 95-109.

Liboriussen, L., Jeppesen, E., Bramm, M.E., Majbritt, F.L., 2005. Periphyton macroinvertebrate interactions in light and fish manipulated enclosures in a clear and a turbid shallow lake. Aquat. Ecol. 39, 23-29.

Moss, K.R.K., Moss, S.M., 2004. Effects of artificial substrate and stocking density on the nursery production of pacific white shrimp Litopenaeus vannamei. J. world Aquacult. Soc. $35,536-542$.

Motoda, 1959. Devices of simple plankton apparauts. Memoirs. Faculty of Fisheries. Hokkaido University 7, 73-94.

Ramesh, T.J., Shankar, K.M., Mohan, C.V., Varghese, T.J., 1999. Comparison of three plant substrates for enhancing carp growth through bacterial biofilm. Aquac. Eng. 19, 119-131.

Richard, M., Archambault, P., Thouzeau, G., McKindsey, C.W., Desrosiers, G., 2007. Influence of suspended scallop cages and mussel lines on pelagic and benthic 
biogeochemical fluxes in Havre-aux-Maisons Lagoon, Îles-de-la-Madeleine (Quebec, Canada). Can. J. Fish. Aquat. Sci. 64, 1491-1505.

Shapiro, S.S., Wilk, M.B., 1965. An analysis of variance test for normality (complete samples). Biometrika 52, 591-611.

Steinman, A.D., 1996. Effect of grazers on freshwater benthic algae, Algal ecology: freshwater benthic ecosystems. Academic Press, San Diego, California, pp. 341-373.

Umesh, N.R., Shankar, K.M., Mohan, C.V., 1999. Enhancing growth of common carp, rohu an Mozambique tilapia through plant substrate: the role of bacterial biofilm. Aquac. Int. 7, 251-260.

van Dam, A.A., Beveridge, M.C.M., Azim, M.E., Verdegem, M.C.J., 2002. The potential of fish production based on periphyton. Rev. Fish Biol. Fish. 12, 1-31.

Vermaat, J.E., 2005. Periphyton dynamics and influencing factors. In: Azim, M.E., Beveridge, M.C.M., van Dam, A.A., Verdegem, M.C.J. (Eds.), Periphyton: Ecology, exploitation and management. SPI publisher systems, pp. 35-49.

Welcomme, R.L., 1972. An evaluation of the acadja methods of fishing as practised in the coastal lagoons of Dahomey (West Africa). J. Fish Biol. 4, 39-45. 


\section{Tables}

Table 1

Results of analyses of variance (ANOVAs) testing the effect of substrate type (TYPE: W: wooden poles, S: fiber-glass strip, m: mosquito screen, M: garden netting), submersion time (TIME: $T_{15 d}, T_{30 d}$ ) and their interactions on periphyton dry weight (DW), ash free dry weight (AFDW), Chlorophyll $a$ (Chl $a$ ), Phaeophytin (Phaeo $a$ ), \% Phaeo $a$ (Phaeo $a$. (Chl $a$ +Phaeo $a)^{-1}$ ) and autotrophic index (AI: AFDW.Chl $a^{-1}$ ) observed on collected substrates. df: degrees of freedom, MS: mean square, F: Fischer, $* \mathrm{P}<0.05$, ** $\mathrm{P}<0.01$, *** $\mathrm{P}<0.001$

\begin{tabular}{|c|c|c|c|c|c|c|c|c|c|c|}
\hline $\begin{array}{c}\text { Variation } \\
\text { source }\end{array}$ & df & MS & $\mathbf{F}$ & $\mathbf{P}$ & MS & $\mathbf{F}$ & $\mathbf{P}$ & MS & $\mathbf{F}$ & $\mathbf{P}$ \\
\hline & \multicolumn{4}{|c|}{$\log D W$} & \multicolumn{3}{|c|}{$\log (A F D W+1)$} & \multicolumn{3}{|c|}{ Al } \\
\hline TYPE & & 0.473 & 6.71 & $0.0022 * *$ & 0.552 & 6.79 & $0.0021 * *$ & $2 E+07$ & 8.48 & $0.0006 * * *$ \\
\hline TIME & & 7.521 & 106.71 & $<0.0001 * * *$ & 6.244 & 76.86 & $<0.0001 * * *$ & $1 E+08$ & 32.82 & $<0.0001 * * *$ \\
\hline TYPE X TIME & & 0.197 & 2.79 & 0.0645 & 0.119 & 1.46 & 0.2529 & $2 E+07$ & 6.00 & $0.0038 * *$ \\
\hline \multirow{2}{*}{ Error } & 22 & 0.070 & & & 0.081 & & & $3 E+06$ & & \\
\hline & \multicolumn{4}{|c|}{$\mathrm{Chl} a$} & \multicolumn{3}{|c|}{ Phaeo $a$} & \multicolumn{3}{|c|}{$\%$ Phaeo $a$} \\
\hline TYPE & & 0.157 & 15.89 & $<0.0001 * * *$ & 0.013 & 6.46 & $0.0025 * *$ & 217.81 & 20.98 & $<0.0001 * * *$ \\
\hline TIME & 1 & 0.202 & 20.43 & $0.0002 * * *$ & 0.105 & 52.08 & $<0.0001 * * *$ & 119.05 & 11.47 & $0.0025 * *$ \\
\hline TYPE X TIME & 3 & 0.028 & 2.82 & 0.0615 & 0.004 & 1.86 & 0.1643 & 53.40 & 5.14 & $0.0072 * *$ \\
\hline Error & 23 & 0.010 & & & 0.002 & & & 10.38 & & \\
\hline
\end{tabular}


Table2

Results of ANOVAs testing the effect of substrate type (TYPE: W: wooden poles, S: fiberglass strips, m: mosquito screen, M: garden netting), submersion depth (DEPTH: 1: 0-15 cm; 2: $15-30 \mathrm{~cm}, 3: 30-45 \mathrm{~cm}, 4: 45-60 \mathrm{~cm}, 5: 60-75 \mathrm{~cm})$ and their interactions on Periphyton dry weight (DW), ash free dry weight (AFDW), chlorophyll (Chl $a$ ), phaeophytin (Phaeo $a$ ) and \% Phaeo $a$ (Phaeo $a$.(Chl $a+$ Phaeo $a)^{-1}$ ) and autotrophic index (Al: AFDW.Chl $a^{-1}$ ) observed on collected substrates. df: degrees of freedom, SS: sum square, MS: mean square, F: Fischer, $* \mathrm{P}<0.05, * * \mathrm{P}<0.01, * * * \mathrm{P}<0.001$

\begin{tabular}{|c|c|c|c|c|c|c|c|c|c|c|}
\hline $\begin{array}{c}\text { Variation } \\
\text { source }\end{array}$ & df & MS & $\mathbf{F}$ & $\mathbf{P}$ & MS & $\mathbf{F}$ & $\mathbf{P}$ & MS & $\mathbf{F}$ & $\mathbf{P}$ \\
\hline & & \multicolumn{3}{|c|}{$\sqrt{\mathrm{DW}}$} & \multicolumn{3}{|c|}{$\log ($ AFDW +1$)$} & \multicolumn{3}{|c|}{$\log A \mid$} \\
\hline TYPE & 3 & 0.02 & 0.21 & 0.8904 & 0.02 & 1.35 & 0.2786 & 3.21 & 6.38 & 0.0021 ** \\
\hline DEPTH & 4 & 0.36 & 3.48 & $0.0204 *$ & 0.05 & 2.64 & 0.0556 & 3.72 & 7.40 & $0.0004 * * *$ \\
\hline TYPE $\times$ DEPTH & 12 & 0.05 & 0.53 & 0.8774 & 0.01 & 0.79 & 0.6563 & 0.50 & 0.99 & 0.4823 \\
\hline \multirow[t]{2}{*}{ Error } & 27 & 0.10 & & & 0.02 & & & 0.50 & & \\
\hline & & \multicolumn{3}{|c|}{$\log C h l a$} & \multicolumn{3}{|c|}{$\log$ Phaeo $a$} & \multicolumn{3}{|c|}{ \% Phaeo $a$} \\
\hline TYPE & 3 & 1.87 & 21.56 & $<0.0001 * * *$ & 0.39 & 2.07 & 0.1255 & 375.89 & 20.87 & $<0.0001$ *** \\
\hline DEPTH & 4 & 8.02 & 92.26 & $<0.0001 * * *$ & 7.76 & 40.86 & $<0.0001 * * *$ & 36.88 & 2.05 & 0.1128 \\
\hline TYPE $\times$ DEPTH & 12 & 0.11 & 1.31 & 0.2658 & 0.25 & 1.32 & 0.2587 & 30.57 & 1.70 & 0.1176 \\
\hline Error & 30 & 0.09 & & & 0.19 & & & 18.01 & & \\
\hline
\end{tabular}




\section{Table 3}

Results of ANOVAs testing the effect of periphyton sampling method (SAMPLING: T: total vs. S-5: addition of all five sub-samples and vs. S-3: addition of three sub-samples 0: 0-15 $\mathrm{cm}, 3:$ 30-45, 5: 60-75 cm), substrate type (TY PE: W: wooden poles, S: fiber-glass strips, m: mosquito screen, M: garden netting) and their interactions on Periphyton dry weight (DW), ash free dry weight (AFDW), Chlorophyll $a$ (Chl $a$ ) and phaeophytin (Phaeo $a$ ) observed on collected substrates. df: degrees of freedom, MS: mean square, F: Fischer, $* \mathrm{P}<0.05, * * \mathrm{P}<$ $0.01, * * * \mathrm{P}<0.001$

\begin{tabular}{|c|c|c|c|c|c|c|c|c|c|c|c|c|}
\hline $\begin{array}{l}\text { Variation } \\
\text { source }\end{array}$ & df MS & $\mathbf{F}$ & $\mathbf{P}$ & MS & $\mathbf{F}$ & $\mathbf{P}$ & MS & $\mathbf{F}$ & $\mathbf{P}$ & MS & $\mathbf{F}$ & $\mathbf{P}$ \\
\hline & \multicolumn{3}{|c|}{$\log$ DW } & \multicolumn{3}{|c|}{$\log$ AFDW } & \multicolumn{3}{|c|}{$\mathrm{Chl} a$} & \multicolumn{3}{|c|}{ Phaeo $a$} \\
\hline SAMPLING (S-5 vs. T) & 13.838 & 74.62 & $<0.0001 * * *$ & 24.383 & 130.80 & $<0.0001 * * *$ & 0.085 & 9.30 & $0.0069 * *$ & 0.017 & 6.46 & $0.0205 *$ \\
\hline TYPE & 30.118 & 2.30 & 0.1124 & 0.626 & 3.36 & $0.0419 *$ & 0.156 & 17.09 & $<0.0001 * * *$ & 0.008 & 3.09 & 0.0532 \\
\hline SAMPLING $\times$ TYPE & 30.109 & 2.11 & 0.1342 & 0.454 & 2.44 & 0.0980 & 0.028 & 3.08 & 0.0537 & 0.007 & 2.67 & 0.0786 \\
\hline Error & 180.051 & & & 0.186 & & & 0.009 & & & 0.003 & & \\
\hline SAMPLING (S-3 vs.T) & 13.833 & 65.13 & $<0.0001 * * *$ & 23.978 & 119.66 & $<0.0001 * * *$ & 0.038 & 3.03 & 0.0986 & 0.008 & 2.94 & 0.1034 \\
\hline TYPE & 30.129 & 2.19 & 0.1249 & 0.680 & 3.39 & $0.0406 *$ & 0.194 & 15.61 & $<0.0001 * * *$ & 0.009 & 3.35 & $0.0421 *$ \\
\hline SAMPLING $\times$ TYPE & 30.105 & 1.79 & 0.1858 & 0.368 & 1.84 & 0.1763 & 0.029 & 2.34 & 0.1074 & 0.007 & 2.53 & 0.0895 \\
\hline Error & 180.059 & & & 0.200 & & & 0.012 & & & 0.003 & & \\
\hline
\end{tabular}




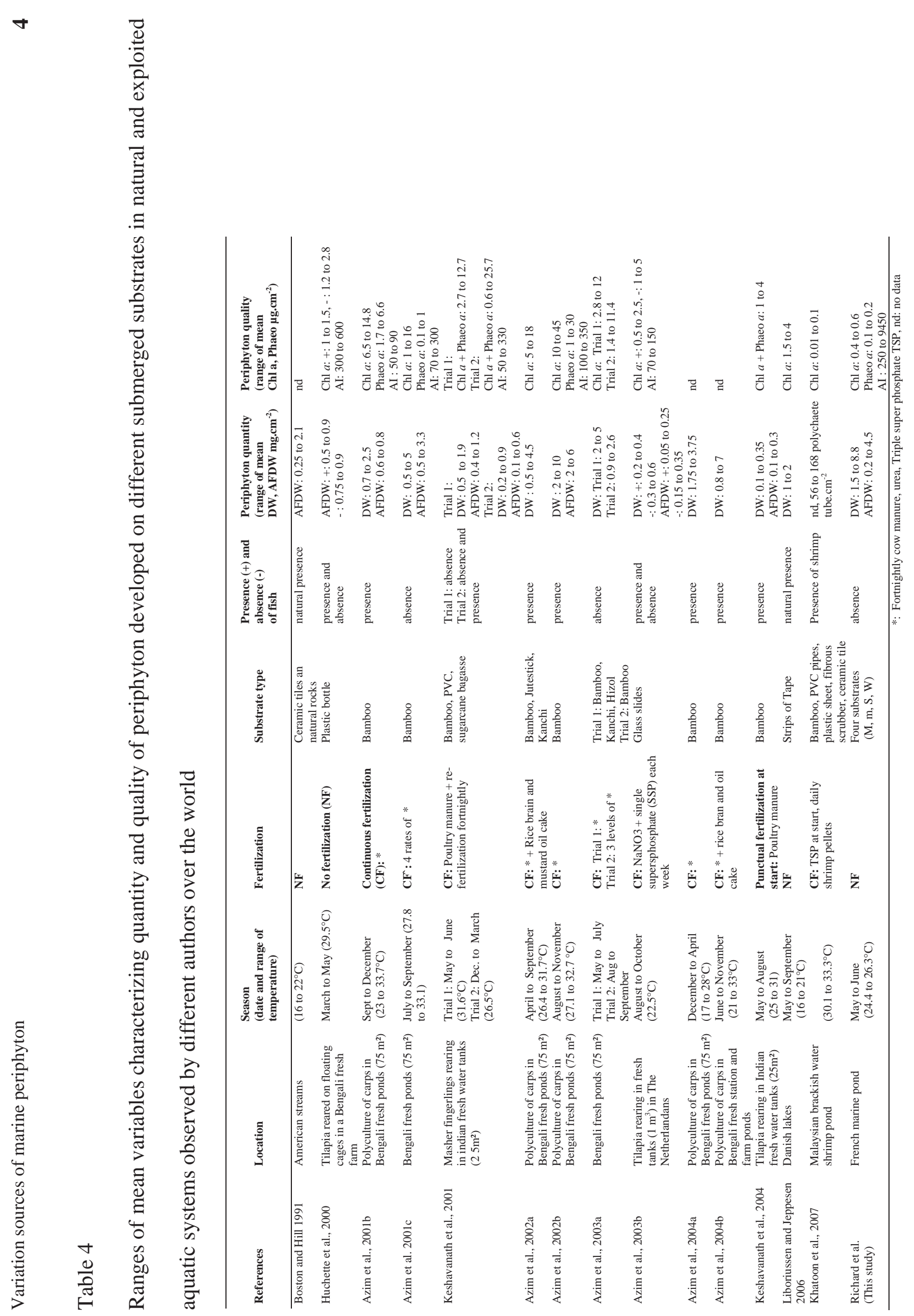




\section{Figures captions}

Fig. 1: Pictures and schemes of the four types of periphyton substrate deployed in the marine pond: a) wooden poles (W), b) fiber-glass strips (S), b) mosquito screen (m) and d) garden netting $(\mathrm{M})$

Fig. 2: a) Scheme of sub-sampling of the submerged substrate surface carried out al ong the submersion depth gradient, b) scheme of three methods of sampling (Total , 5 sub-samples, 3 sub-samples)

Fig. 3: Mean ( \pm Standard Error) periphyton dry weight $(a, c)$ and chlorophyll pigment $(b, d)$ observed on substrates according to $a, b)$ submersion time (TIME: $T_{15 d}, T_{30 d}$ ) and $c, d$ ) substrate type (TYPE: W: wooden poles, S: fiber-glass strips, m: mosquito screen, M: garden netting). Different letters indicate statistically difference among variation source. Lower cases are linked to means represented by the bars of the bottom (AFDW, Chl a). Capital letters are associated with DW and Phaeo a means

Fig. 4: Mean ( \pm Standard Error) periphyton dry weight (a) and chlorophyll pigment (b) observed on substrates according to the submersion depth (DEPTH; 1: 0-15 cm; 2: $15-30 \mathrm{~cm}$; 3: $30-45 \mathrm{~cm}, 4: 45-60 \mathrm{~cm}, 5: 60-75 \mathrm{~cm})$. Different letters indicate statistically difference among depth. Lower cases are linked to means represented by the bars of the bottom (AFDW, Chl a). Capital letters are associated with DW and Phaeo a means

Fig. 5: Mean ( \pm Standard Error) periphyton dry weight (a) and chlorophyll pigment (b) observed on substrates according to the sampling method (SAMPLING: S-5: addition of five sub-samples; T: total sample; S-3: addition of three sub-samples 0: 0-15 cm, 3: 30-45, 5: 60$75 \mathrm{~cm})$. Different letters indicate statistically difference among sampling method. Normal letters are used for the T vs. S-5 comparison, whereas ital ic letters are used for the T vs. S-3 comparison. Lower cases are linked to means represented by the bars of the bottom (AFDW, Chl a). Capital letters are associated with DW and Phaeo a means 
Figures
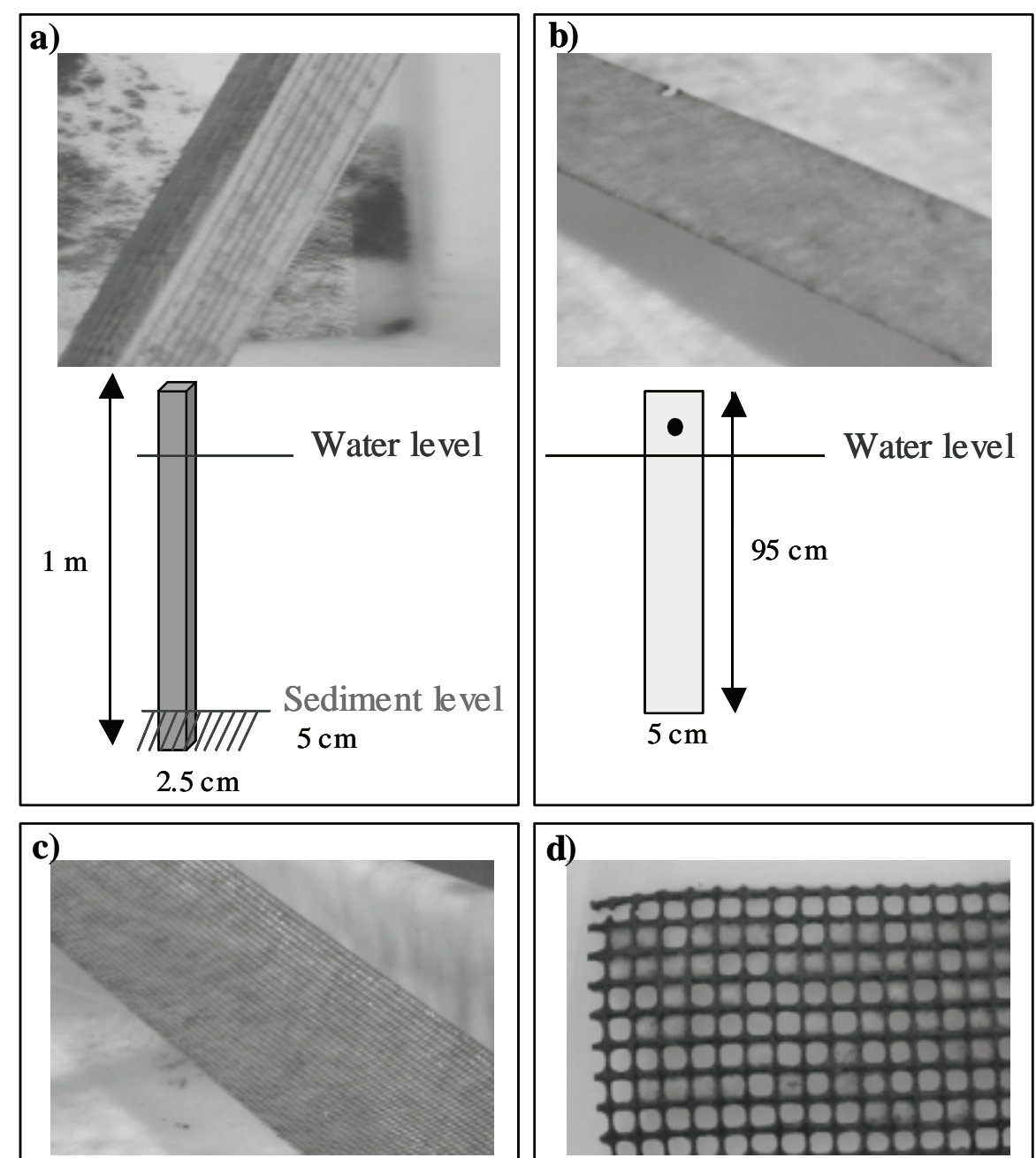

d)
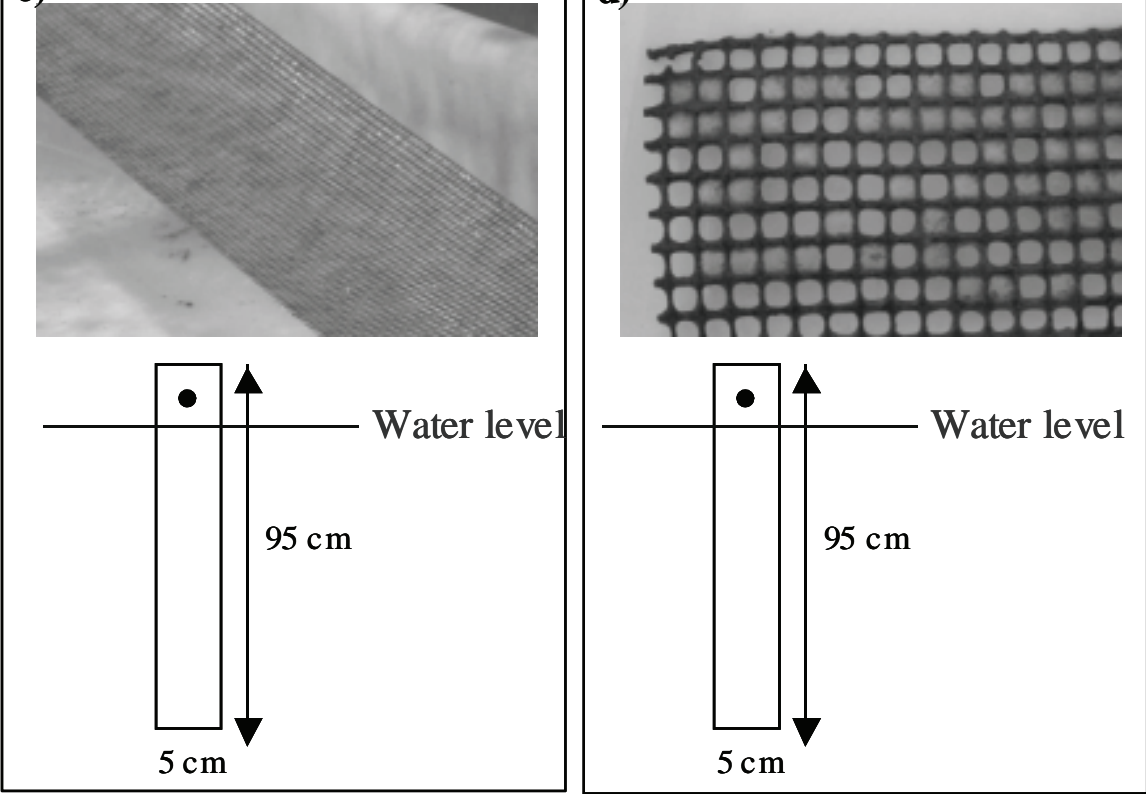

Fig. 1. Richard et al. 
a) Sub-sampling

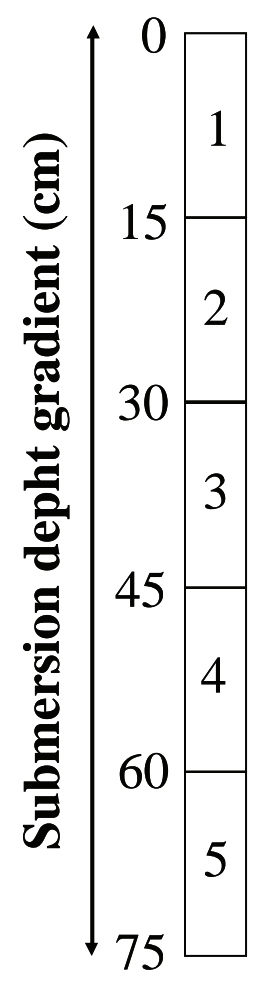

b) Total sample 5 sub-samples 3 sub-samples S-5

S-3

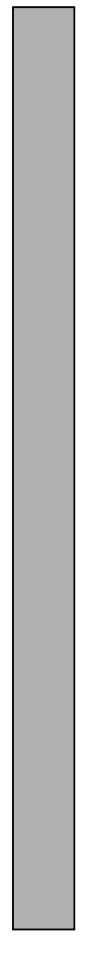

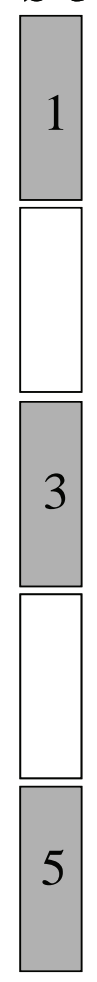

Fig.2. Richard et al. 

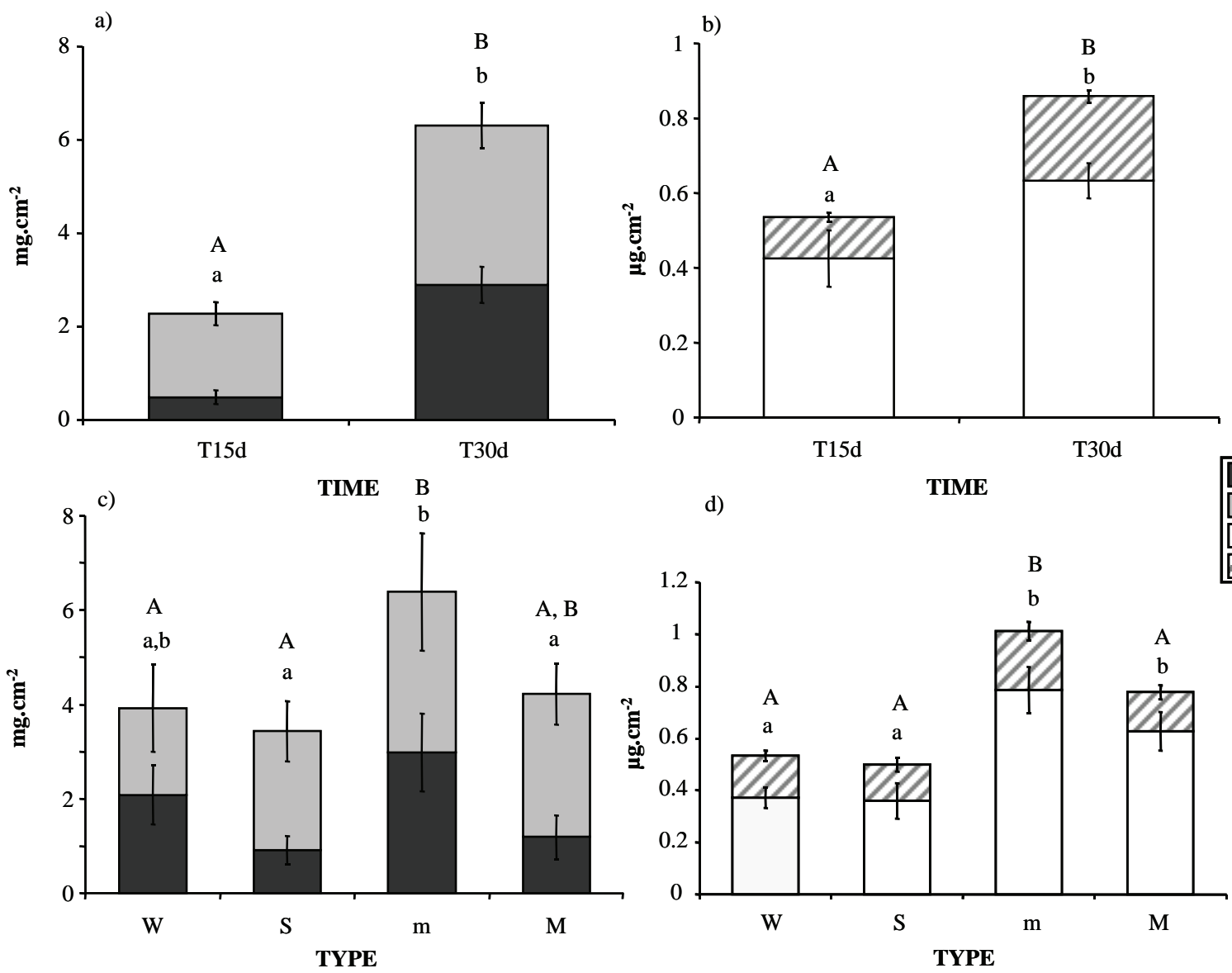

d)

AFDW

$\square$ Chl a

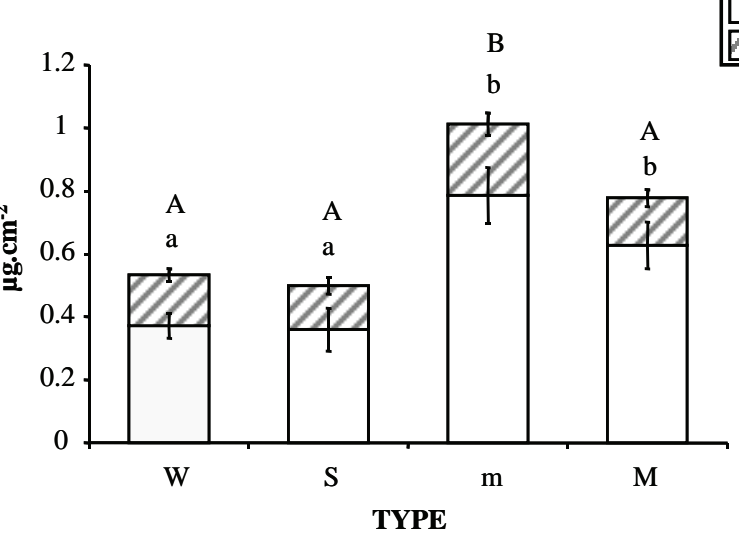

Phaeo a

Fig. 3. Richard et al . 

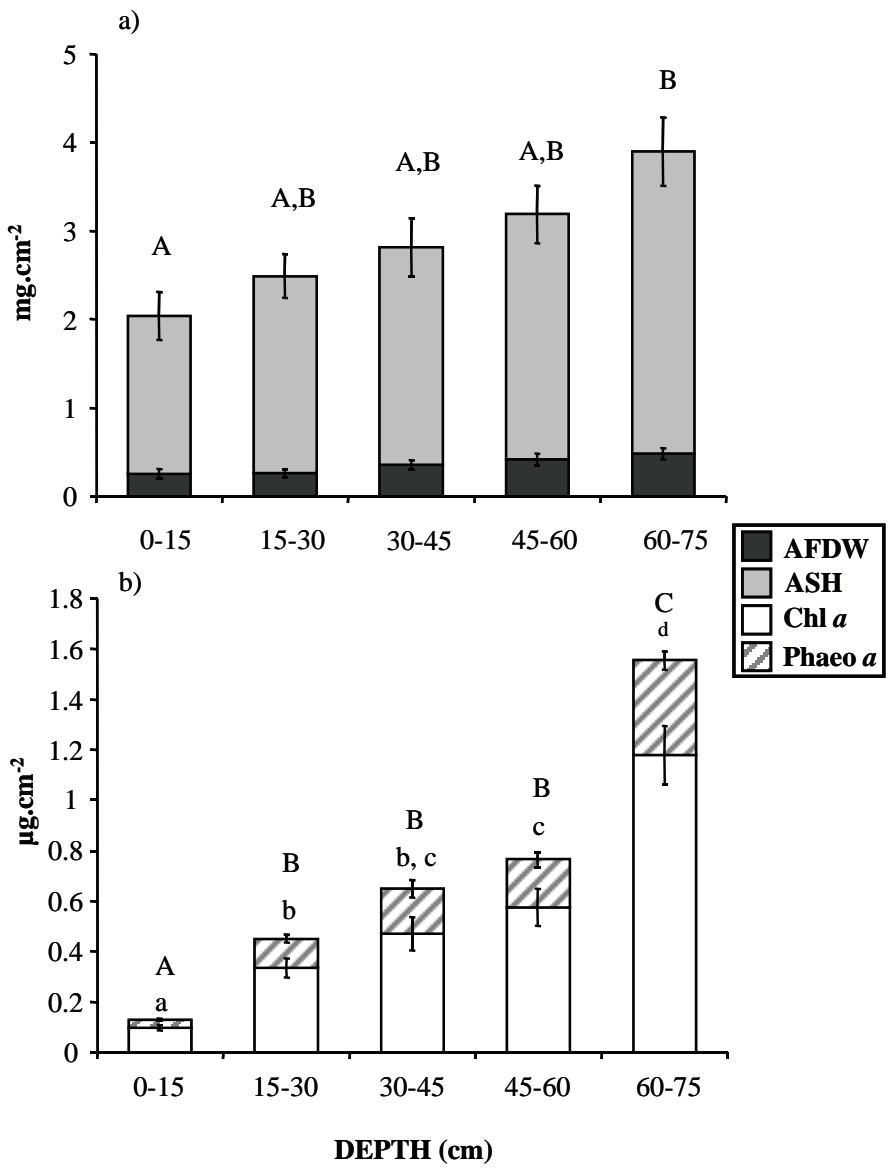

Fig. 4. Richard et al. 

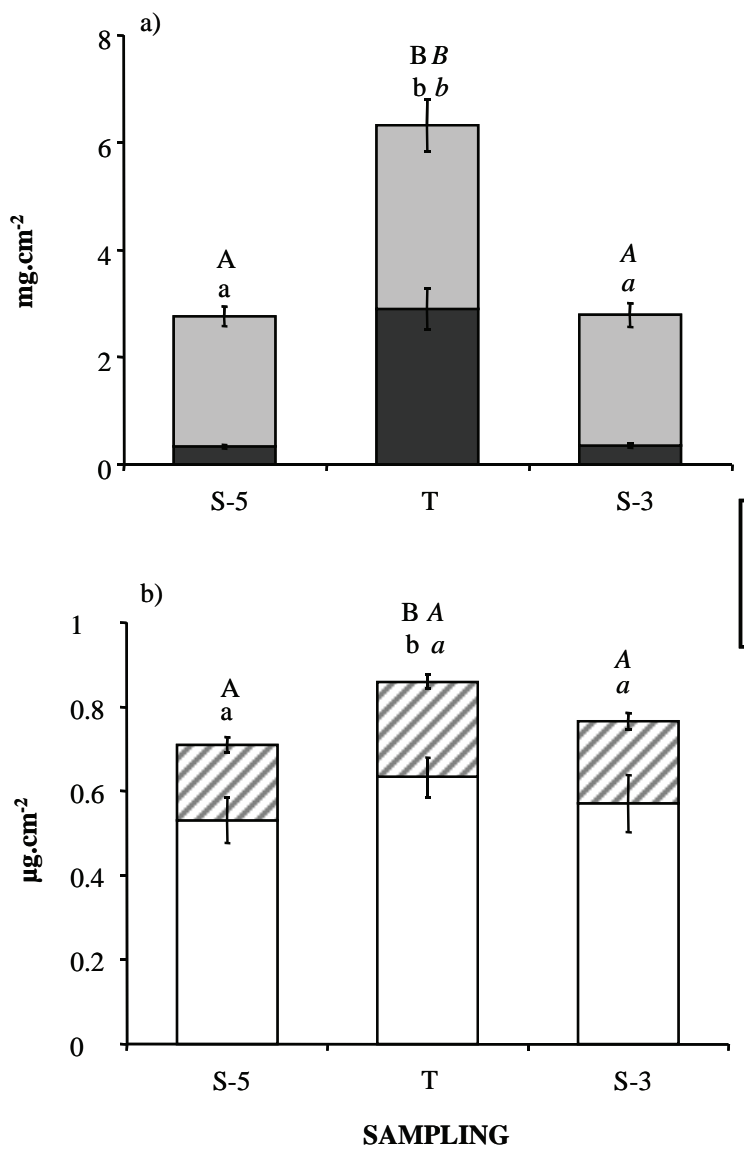

Phaeo a

Fig. 5. Richard et al . 